IRA-International Journal of Education \& Multidisciplinary Studies

ISSN 2455-2526; Vol.13, Issue 02 (November, 2018)

Pg. no. 8-12.

Institute of Research Advances

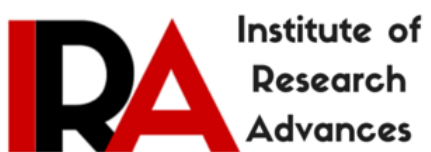

http://research-advances.org/index.php/IJEMS

\title{
Piano Performing Art of Russia: Major Development Trends in the 20th Century
}

\section{Zhou BeiBei}

Academy of Arts, Jingchu University of Technology, Xiangshan Avenue No.33, Jingmen City, Hubei Province, P. R. China.

Type of Review: Peer Reviewed.

DOl: http://dx.doi.org.10.21013.jems.v13.n2.p1

\section{How to cite this paper:}

BeiBei, Z. (2018). Piano Performing Art of Russia: Major Development Trends in the 20th Century. IRA International Journal of Education and Multidisciplinary Studies (ISSN 2455-2526), 13(2), 8-12.doi: http://dx.doi.org.10.21013.jems.v13.n2.p1

(C) Institute of Research Advances.

This work is licensed under a Creative Commons Attribution-Non Commercial 4.0 International License subject to proper citation to the publication source of the work.

Disclaimer: The scholarly papers as reviewed and published by the Institute of Research Advances (IRA) are the views and opinions of their respective authors and are not the views or opinions of the IRA. The IRA disclaims of any harm or loss caused due to the published content to any party.

Institute of Research Advances is an institutional publisher member of Publishers Inter Linking Association Inc. (PILA-CrossRef), USA. The institute is an institutional signatory to the Budapest Open Access Initiative, Hungary advocating the open access of scientific and scholarly knowledge. The Institute is a registered content provider under Open Access Initiative Protocol for Metadata Harvesting (OAI-PMH).

The journal is indexed \& included in WorldCat Discovery Service (USA), CrossRef Metadata Search (USA), WorldCat (USA), OCLC (USA), Open J-Gate (India), EZB (Germany) Scilit (Switzerland), Airiti (China), Bielefeld Academic Search Engine (BASE) of Bielefeld University, Germany, PKP Index of Simon Fraser University, Canada. 


\begin{abstract}
The purpose of the article is to identify features of the development of piano playing in Russia in the $20^{\text {th }}$ century in the context of key trends and leading genre and styles.In connection with the goal, the following tasks were identifying: to consider Essence of Definition "Russian Piano School"; to characterize Russian Piano School in Conditions of Reorganization of System of Music Education after 1917; to consider Russian Piano Performance Art in 1930-1950s; to describe Russian Pianism in 1960 1990s.This work elucidates the Russian Piano School's evolving characteristics, its tendencies and styles, and how it received such authority and respect throughout the world. This article also reveals the Russian Piano School's principal musical pedagogical figures, and how diverse and original they are, especially modern Russian pianists. The unique and pivotal influence of these artists is clearly defined in the context of an emerging and distinct Russian Piano School.
\end{abstract}

Keywords: Russian piano school, music education, pianism, piano performance art, pianists

\title{
1. Introduction
}

More than one hundred years have passed since the birth of the Russian piano school. Russian pianistic school enjoys well-deserved worldwide recognition. Abroad widely known names of outstanding pianists Anton and Nikolay Rubinstein, Sergei Rachmaninov, Heinrich Neuhaus, Lev Oborin, Sviatoslav Richter, Vladimir Sofronitzki.

Russian piano music came to the world stage in the second half of the nineteenth century and immediately forced to talk about themselves as unique and bright phenomenon. With this time related to the activities of composers, performers and world class faculty - such as Anna Yesipova, Felix Blumenfeld, Leonid Nikolayev, Maria Barinova, Dmitry Shostakovich, Sergey Prokofiev, Emil Gilels.

The great traditions of the Russian piano school continue, undiminished by time. They carry on from generation to generation, from teacher to student, from hands to hands. These traditions bring to us the experience of great art, and unforgettable moments of pleasure in music.

The Russian music education system has always been rather shrouded in mythology and outsiders have tended to regard the Russian approach as mechanical, with an extreme emphasis on highly-honed technique over musicianship. Critics of the Russian School point to an emphasis on power in playing, which can be overwhelming, and lacking in light and shade, and an undue focus on producing competition winners, which is of course good for national prestige.

The Russian School is notable for its full orchestral, projected sound, physicality in playing (an emphasis on use of the arms which drag the hands up and down the keyboard) and the ability to focus talent from a very young age (the result of a national network of specialist state music schools where students learn the rudiments of music in detail). The great pianist-teachers such as A. B. Goldenweiser and Heinrich Neuhaus sought to discover and encourage these characteristics in their pupils, and the Russian Piano School has produced many outstanding pianists including Rachmaninov, Prokofiev, Richter, Gilels, Ashkenazy, Leonskaja and Pletnev - all musicians who display prodigious and immaculate technique, passion, dramatic power, intense emotional expressiveness and physical vitality in their playing. Younger graduates of the Russian School include Evgeny Kissin, Rustem Hayroudinov, Denis Matsuev, Daniil Trifonov and Anna Tsybuleva.

The actuality of the study determined the current situation in China is characterized by the growth of national consciousness, a qualitative change of value orientations, the appeal to universal and national traditions. The problem of the relation of spirituality, culture and education actualizarea during periods of changing lifestyles and tenets in the society. It is education, due to its mass and systematic "translates" the values of the world culture in the sphere of the emerging new social consciousness, thus influencing the processes taking place in the spiritual, cultural, economic and political life of the country.

The object of study was Piano Performance Art in Russia of the 20th century. The subject of study was composition and performance skills of the leading Russian pianists of the 20th century. The purpose of the article is to identify features of the development of Piano Performance Art in Russia in the $20^{\text {th }}$ century in the context of key trends and leading genre and styles.

\section{First task -to consider Essence of Definition "Russian Piano School"}

The concept of "piano school" includes different facets. These are: 1) an educational structure headed by a prominent musician (for example, Heinrich Neuhaus, Alexander Goldenweiser); 2) an educational, creative team, a community of pianists working under the guidance of the head of the school to solve any educational or creative tasks; 3 ) a direction that under certain socio-historical conditions acquires a national or international 
character (German, French, Russian piano schools); 4) the methodical system of a particular teacher, which is published in printed form as a teaching aid, a collection of sketches or exercises ("Steps Toward Parnassus" by Muzio Clementi, etudes "School of fluency", op. 299 Carl Czerny and others).

Russian piano art took shape in the process of dialectical interaction of the general and the individual, national and international. Its formation began in the second half of XVIII. The result of the development of the Russian pianistic school in the twentieth century was one of the world's largest and most authoritative pianistic schools. It is based on rich traditions, generations of Russian musicians worked out by creativity. At present, the Russian musical and pedagogical tradition is a complex, multifaceted structure that incorporates various types of musical activity.

\section{3. second task - to characterizeRussian Piano School in Conditions of Reorganization of System of Music Education after 1917}

It was established thatSocial transformations in Russia after 1917 have had a mixed impact on the development of piano performing art. Irreplaceable were the losses from emigration. From Russia left Sergei Vasilyevich Rakhmaninov, Nikolai KarlovichMedtner. The traditions of private home teaching of music were lost, which drastically reduced the level of musical culture of the younger generation. Despite this, Russian pianists managed to preserve the basis of professional music education and strengthen its organizational structure. As a result, of numerous transformations, successful forms of professional music education have been found, preserved in the whole throughout the twentieth century.

The most important factor in preserving the musical culture was the continuation of the activities of the Moscow and Petrograd (later Leningrad) conservatories, in unbearable conditions that support a high level of education.The first stage was formed by children's music schools (since 1933 - seven-year), the second - the school, and the third, the higher - the conservatory. There were also 10-year schools combining 1 and 2 steps. Another positive aspect of the Soviet period - the government gave a real opportunity to teach gifted children.

\section{Third task - to considerRussian Piano Performance Art in 1930-1950s- led to the following conclusion. \\ An outstanding role in pianism in $20^{\text {th }}$ century belongs to two Soviet schools - Moscow (Konstantin Igumnov, Alexander Goldenweiser, Samuel Feinberg, Heinrich Neuhaus and their pupils Lev Oborin, GrigoryGinzburg, Yakov Flier, Yakov Zak, Svyatoslav Richter, Emil Gilels and others) and Leningrad (Leonid Nikolaev and his disciples Maria Yudina, Vladimir Sofronitsky, and others). Continuing and developing on a new basis the realistic traditions of the major representatives of Russian pianism in the late 19th and early 20th centuries (Anton and Nikolas Rubinstein, Anna Yesipova), the best Soviet pianists combined in their play a true and meaningful transfer of the author's design with high technical skill.}

Despite the differences in the content and methods of teaching appropriate to the individual characteristics of these teachers, there were common strategic directions or principles in their activities: 1) movement from the internal to the external, from the artistic image of the performed work to the technical means of its implementation; 2) intellectualization of the learning process; 3) activation of cognitive activity aimed at increasing the independence of students; 4) the moral direction of the educational process; 5) the principle of cooperation between the teacher and students.

\section{Fourth task - to describe Russian Pianism in 1960-1990s}

It was established that the largest Soviet piano schools in the second half of the $20^{\text {th }}$ century were given by a number of high-performing musicians and highly skilled piano teachers such as Emil Gilels, Viktor Merzhanov, Tatyana Nikolaeva, Stanislav Neuhaus, Lev Vlasenko, Yevgeny Malinin, Dmitry Bashkirov, Vladimir Krainev, Alexei Lyubimov, Mikhail Pletnev. The achievements of the Soviet (after 1991 - Russian) pianism led to a worldwide recognition of the national pianistic school. Many Soviet pianists received awards (including the first) at international competitions.

The piano art of Russian pianists of the second half of the 20th century fits in two directions: expressive and graphic. Thus, in piano compositions the performers of the "expressive direction" express the idea of the composer through the prism of his spiritual world, the attitude towards the work, making searches for it in the historical and philosophical panorama. Pianists of the "pictorial direction" show us the idea of the work, its meaning in the context of their personal professional capabilities, drawing with images an image.Both these directions continue to develop in the Russian pianism of the 21 st century. 


\section{References}

[1] Artynova, L. A.Stranizy istorii . L. A. Artynova . Metodizheskie zapiski po voprosam muzykalnogo obrazovania. $-M$. ,1966. - S. 7-40.

[2] Barnes, Ch. Russian Piano School . Ch. Barnes. - Kahn \& Averill, 2007. - 256 p.

[3] Belina, A. The Master of Moscow. A. Belina . The International Piano Magazine. - 2007. - Jan-Feb. - pp. $62-65$.

[4] Berman, B. Notes from the pianist's bench . B. Berman. - New Haven : Yale University Press, 2000. - 256 p.

[5] Bucur, M. Russia and Eastern Europe . M. Bucur, B. Eklof . Amova, R. Comparative Education: The Dialectic of the Global and the Local . R. Amova, C. Torres. - Maryland: Rowman \& Littlefield Publications, 2007. - pp. 31-43.

[6] Chang, Anita Lee-ling. The Russian School of Advanced Piano Technique: Its History and Development from the 19th to 20th Cent. : DMA diss. . Anita Lee-ling Chang; University of Texas at Austin, 1994. - 175 p.

[7] Chiao, Y. P. The Changing Style of Playing Rachmaninoff's Piano Music, Unpublished PhD dissertation . Y. P. Chiao; King's College, University of London. - London, 2012. - 468 p.

[8] Conus, O. Fundamentals of Piano Technique - The Russian Method: Newly Revised by James \& Susan McKeever . O. Conus, L. Conus; edit. J. \& S. McKeever. - Hal Leonard; Revised edition, 2016. - 88 p.

[9] Dart, Thurston. The Interpretation of Music. Th. Dart. - London and New York: Hutchinson's University Library, 1954. - $192 \mathrm{p}$.

[10] Dreyfus, L. Beyond the Interpretation of Music . L. Dreyfus . Dutch Journal of Music Theory: Tijdschrift voor Muziektheorie. - 2007. -No. 12. - pp. 253-272.

[11]Eco, U. Interpretation and overinterpretation . U. Eco with R. Rorty, J. Culler, Ch. Brooke-Rose, ed. S. Collini. Cambridge ; New York : Cambridge University Press, 1992. - ix, 151 p.

[12] Frolova-Walker, M. Music and Soviet Power, 1917-1932 . M. Frolova-Walker, J. Walker. - Woodbridge: Boydell Press, 2012. $-432 \mathrm{p}$.

[13] Goldenweiser, A. Sovety pedagoga-pianista [Advice from a Pianist and Teacher] . A. Goldenweiser . Pianisty rasskazyvayut, No. 1. - Moscow: Muzyka, 1990. - PP. 119-132.

[14] Gulina, M. Post USSR Countries . M. Gulina, M. Valk-Falk . Hargreaves, D. and North, A. (ed.) Musical Development and Learning: an International Perspective . D. Hargreaves, A. Noth. - London: Continuum, 2001. - pp. 145-160.

[15] Habokian, L. Music of the Soviet Era: 1917-1991 . L. Habokian. - Taylor \& Francis, 2016. - 512 p.

[16] Hamilton, K. The Virtuoso Tradition . K. Hamilton . Rowland, D. The Cambridge Companion to the Piano . D. Rowland. - Cambridge: Cambridge University Press, 1998. - pp. 57-74.

[17] Kofman, I. The history of the Russian piano school: Individuals and traditions . I. Kofman. -University of Miami, 2001. $-218 \mathrm{p}$.

[18] Lee-Ling Chang, A. The Russian school of advanced piano technique : its history and development from the 19th to the 20th century . A. Lee-Ling Chang. - Ann Arbor Mich. : UMI, 1998. - xiii, 161 p.

[19] Lehmann, A. Expression and Interpretation . A. Lehmann . Psychology for Musicians: Understanding and acquiring the skills. -New York: Oxford University Press, 2007. - pp. 85-106.

[20] Leikin, A. Not Set in Stone: Mikhail Pletnev's Rewrite of Scriabin's Piano Concerto . A. Leikin . Performance Practice Review. Vol. 22. - 2017. - No. 1. - Article 4.

[21] Lourenço, S. European Piano Schools : Russian, German and French classical piano interpretation and technique. S. Lourenço . Journal of Science and Technology of the Arts. Vol. 2. - 2010. - No 1. - pp. 6-14.

[22] Lvova, E. I. Vydajushchiesa sovetskie pedagogi 30-50-h godov ("Moskovskaja pianisticheskaja shkola") - ih prinzypy i metody prepodavania: avtoref. dis. ... PhD . E. I. Lvova. - M. , 1988. $-18 \mathrm{~s}$.

[23] Maes, F. A History of Russian Music: From Kamarinskaya to Babi Yar . F. Maes. -California: University of California Press, 2006. $-441 \mathrm{p}$.

[24] March, E. Great Contemporary Pianists Speak for Themselves . E. March. - Courier Corporation, 2012. - 480 p.

[25] Mirvis, G. Pedagogicheskie vzglyady Ya. I. Zaka [Yakov Zak as Teacher] . G. Mirvis, O. Stupakova . Voprosy fortepiannogo ispolnitel'stva, No. 2, Moscow: Muzyka, 1968. - pp. 228-251.

[26] Monsaingeon, M. B. Sviatoslav Richter: Notebooks and Conversation . M. B. Monsaingeon. - London: Faber \& Faber, 2001. -464 p.

[27] Moshevich, S. Dmitri Shostakovich, Pianist . S. Moshevich. - McGill-Queen's Press - MQUP, 2004. - 222 p

[28] Neuhaus, H. The Art of Piano Playing. H. Neuhaus, edit. by K. A. Leibovitch. - Kahn \& Averill, 2016. - 256 p.

[29] Nguyen, M. T. The Effects of Russian Piano Pedagogy on Vietnamese Pianists, with Comparisons of Effects of Vietnamese Piano Pedagogy and UK Piano Pedagogy, Unpublished PhD dissertation, University of New South Wales. $-2007 .-505 \mathrm{p}$.

[30] Nikolaev, A. The Russian school of piano playing . A. Nikolaev, compiled by E. Kisell, V. Natanson, A. Nikolaev and N. Sretenskaya ; general editor, A. Nikolaev ; translated into English by Narineh Harutyunyan and Martin Hughes. Boosey \& Hawkes, 1978. - 38 p.

[31] Oborin, L. 'O nekotorykh printsipakh fortepiannoi tekhniki' [Some Principles of Pianoforte Technique] . L. Obobrin . Voprosy fortepiannogo ispolnitel'stva, No. 2. - Moscow: Muzyka, 1968. - pp. 71-80.

[32] Paperno, D. Notes of a Moscow Pianist . D. Paperno. - Oregon: Amadeus Press, 1998. - 238 p.

[33] Parakhina, D. On the Tradition of the Russian Piano Pedagogy . D. Parakhina . The Pianist. - 2012. - Vol. 3. - July. pp. 16-21.

[34] Rasmussen, K. A. Sviatoslav Richter: Pianist . K. A. Rasmussen; translated by R. Dees. - Boston: Northeastern University Press, 2010. - 303 p.

[35] Philip, R. Performing Music in the Age of Recording . R. Philip. - New Haven: Yale, 2004. - 304 p.

[36] Pisarenko, M. Cultural Influences upon Soviet-Era Programmatic Piano Music for Children : A document submitted in partial fulfillment of the requirements for the Master of Musical Art . M. Pisarenko; University of Nevada, Las Vegas. - Las Vegas, 2017. - 125 p. 
[37] Rego, J. A. Skryabin, Rakhmaninov, and Prokofiev as Composer-Pianists: The Russian Piano Tradition, Aesthetics, and Performance Practices, Unpublished PhD dissertation, Princeton University. - 2012. - 508 p.

[38] Rimm, R. The composer-pianists: Hamelin and The Eight . R. Rimm. - Portland: Amadeus Press, 2002. -340 p.

[39] Rink, J. Musical Performance: A Guide to Understanding . J. Rink. - Cambridge University Press, 2002. - 245 p.

[40] Robert, W. Piano Study in Soviet-Russian Schools of Music . W. Robert . The Journal of Research in Music Education, Fall XII. - 1964. - No. 3. - pp. 199-211.

[41] Rowland, D. History of Pianoforte Pedalling . D. Rowland. - Cambridge: Cambridge University Press, 2008. - 208 p.

[42] Rubinstein, A. Autobiography of Anton Rubinstein, 1829-1889 . A. Rubinstein, A. Delano (trans.). - Kessinger Publishing, 2008. - 188 p.

[43] Sandor, G. (1981) On Piano Playing: Motion, sound and expression . G. Sandor. - London: Schirmer, 1981. - 240 p.

[44] Schwarz, B. Music and Musical Life in Soviet Russia, 1917-1970 . B. Schwarz. - Barrie \& Jenkins, 1972. - 550 p.

[45] Schonberg, H. The Great Pianist: From Mozart to the Present . H. Schonberg. - New York: Simon \& Schuster, 1987. $528 \mathrm{p}$.

[46] Sitsky, L. Anton Rubinstein : an annotated catalog of piano works and biography . L. Sitsky. - Westport, CT : Greenwood Press, 1998. - VIII, 221 p.

[47] Shiromoto, T. Japanese Piano Pedagogy and its Russian Influence . Unpublished PhD dissertation, Institute of Education, University of London. - London, 2007. - 458 p.

[48] Sokolov, M. G. Vydayuschieeya Pianisty - Pedagogi o Fortepiannom Obuchenii . M. G. Sokolov . Trudy Kafedry Obuschevo Fortepianno po Metodike Istorii I Teorii Ispolnitelictva . pod. red. S. Hentova. - Moscow, 1991. - No. 1. pp. 74-89.

[49] Sontag, S. Against Interpretation and Other Essays . S. Sontag. - London: Eyre \& Spottiswoode 1967. - 304 p.

[50] Taruskin, R. Defining Russia Musically . R. Taruskin. - Princeton University Press, 2001. - 600 p.

[51] Taruskin, R. Some Thoughts on the History and Historiography of Russian Music . R. Tarushkin . The Journal of Musicology 3.4 - 1984. - Autumn. - pp. 337-338.

[52] Taylor, Ph. S. Anton Rubinstein . Ph. S. Taylor. - Bloomington: Indiana University Press, 2007. - 386 p.

[53] Tzenova, V. Underground Music from the Former USSR . V. Tzenova. - Amsterdam: Harwood, 1997. - 272 p.

[54] Tzipin, G. M. Portrety sovetskih pianistov . G. M. Tzipin. - 2 edit. - M. : Sovietsky kompositor, 1990. - 327, [4] s.

[55] Udin, A. P. Tradizii russkoy fortepiannoy shkoly I sovremennaya praktika obuchenia $v$ muzykal'nyh uchebnyh zavedeni'h KNR . A. P. Udin, Han Mo . Prepodavatel' XXI vek. - 2017. - no. 2-1. - pp. 187-198.

[56] Wagner, I. Producing Excellence: The Making of Virtuosos . I. Wagner. - New Jersey: Rutgers University Press, 2015. $-296 \mathrm{p}$.

[57] Wan, Blanc Chun Pong. Contemporary Russian Piano School Pedagogy and Performance : a thesis submitted for the Degree of Doctor of Philosophy . Blanc Chun Pong Wan; King's College London. - London : University of London, 2016. -379 p.

[58] Wilson, F. (2018). What Distinguishes the Different Schools of Piano Technique?. [online] Interlude.hk. Available at: http://www.interlude.hk/front/schools-influence. [Accessed 20 Nov. 2018].

[59]Zlatar, J. An Introduction to Piano Interpretation . J. Zlatar. - Zagreb, Croatia: Music Academy of Zagreb, 1997. - 171 str. 